\title{
Nitrogen fertilization with conventional and slow-release urea in two forms of application on maize
}

\section{Adubação nitrogenada com ureia convencional e de liberação lenta em dois modos de aplicação na cultura do milho}

\author{
Hianka Carara de SOUZA ${ }^{1}$; Eliete de Fátima Ferreira da ROSA²; Jéssica Fernandes KASEKER ${ }^{3}$ \\ Marcos André NOHATTO4; Mikael Cardoso dos SANTOS ${ }^{5}$ \\ ${ }^{1}$ Acadêmico do curso de Engenharia Agronômica. Instituto Federal Catarinense - Campus Santa Rosa do Sul. \\ Hiankacarara@hotmail.com \\ ${ }^{2}$ Autor para correspondência" Eng. Agr. Doutora em Manejo do Solo, Instituto Federal Catarinense Campus Santa Rosa do \\ Sul. Caixa Postal 04 - Santa Rosa do Sul-SC, eliete.rosa@ifc.edu.br \\ ${ }^{3}$ Eng. Agr. Doutora em Ciência do Solo, Universidade do Estado de Santa Catarina - UDESC. jessica.kaseker@ifc.edu.br \\ ${ }^{4}$ Eng. Agr. Doutor em Fitossanidade, Instituto Federal Catarinense Campus Santa Rosa do Sul. marcos.nohatto@ifc.edu.br \\ ${ }^{5}$ Acadêmico do curso de Engenharia Agronômica. Instituto Federal Catarinense Campus Santa Rosa do Sul. \\ mikaelsantos@outlook.com
}

Recebido em: 31-10-2018; Aceito em: 19-03-2019

\begin{abstract}
Urea is the nitrogen fertilizer most used in agriculture and the most subject to $\mathrm{N}$ losses. Thus, it is important to look for alternatives to reduce these losses and increase agronomic $\mathrm{N}$ use efficiency. In this sense, this study evaluates the effect of split or single application of slow-release and conventional urea in maize development and yield, as well as the fertilizer use efficiency by plants. The experiment was carried out in Santa Rosa do Sul - SC, in a randomized complete block design with 5 treatments and 3 replicates. The treatments evaluated were: control; $100 \%$ of the recommended dose of conventional urea at sowing; $30 \%$ of the recommended dose of conventional urea at sowing and $70 \%$ at topdressing; $100 \%$ of the recommended dose of slow-release urea at sowing; $30 \%$ of the recommended dose of slow-release urea at sowing and $70 \%$ at topdressing. The variables analyzed were ear insertion height, stem diameter, leaf chlorophyll content (R1 stage), yield components, crop yield, and nitrogen use efficiency. The split application of slow-release urea to the soil positively affected stem diameter and nitrogen use efficiency in maize plants, being, therefore, a good fertilization alternative for the crop in the soil and climate conditions of the region.
\end{abstract}

\section{Additional keywords: encapsulated fertilizer; nitrogen; Sulfammo®; Zea mays L.}

\begin{abstract}
Resumo
A ureia é o fertilizante nitrogenado mais empregado na agricultura e, também, o mais sujeito a perdas de $\mathrm{N}$. Por isso, é importante buscar alternativas para reduzir estas perdas e aumentar a eficiência agronômica no uso de $\mathrm{N}$. Diante disso, o objetivo do estudo foi avaliar o efeito da aplicação de ureia de liberação lenta e a convencional, parcelada ou em dose única, no desenvolvimento e na produtividade da cultura do milho, bem como a eficiência do uso destes fertilizantes pelas plantas. O experimento foi realizado em Santa Rosa do Sul - SC, no delineamento experimental de blocos ao acaso, com 5 tratamentos e 3 repetições. Os tratamentos avaliados foram: testemunha; $100 \%$ da dose recomendada de ureia convencional na semeadura; $30 \%$ da dose recomendada de ureia convencional na semeadura e $70 \%$ em cobertura; $100 \%$ da dose recomendada de ureia de liberação lenta na semeadura; 30\% da dose recomendada de ureia de liberação lenta na semeadura e $70 \%$ em cobertura. As variáveis analisadas foram: altura de inserção da espiga, diâmetro do colmo, teor de clorofila da folha (no estádio R1), componentes de rendimento, produtividade da cultura e eficiência do uso de nitrogênio. A aplicação parcelada de ureia de liberação lenta influenciou positivamente o diâmetro do colmo e a eficiência do uso do nitrogênio pelas plantas de milho, sendo, portanto, uma boa alternativa de adubação para a cultura nas condições de solo e de clima da região.
\end{abstract}

Palavras-chave adicionais: fertilizante encapsulado; nitrogênio; Sulfammo®; Zea mays L.

\section{Introduction}

Maize has high economic importance in agricultural production, being consumed and cultivated in several parts of the world due to its nutritional qualities.
The crop has several applications, ranging from animal feed; human food, in the form of flours, oils, and flakes; to the high technology industry, such as biofuel production (Guo et al., 2017). Nitrogen $(\mathrm{N})$ is the nutrient that is most required by the maize crop, and the one 
that overcharges the production of this cereal the most (Civardi et al., 2011).

Among the sources of nitrogen fertilizers used in agriculture, urea stands out as a cheap, easy-to-acquire source with high concentration of this nutrient. However, urea can be easily lost through the processes of erosion, leaching, volatilization, and denitrification (Austin et al., 2013), being considered the most difficult fertilizer to be used in tropical and subtropical soil. In addition to urea, other $\mathrm{N}$ sources are available in the market, such as ammonium sulfate and ammonium nitrate. Moreover, one of the technologies that is gaining ground in agriculture is slow-release fertilizers. After application, these fertilizers delay nutrient solubilization, nutrient availability for absorption, and nutrient use by plants, or significantly prolong the release time of the nutrient in the soil when compared to traditional soluble sources (Chien et al., 2009). In traditional fertilizers, solubilization is linked to edaphoclimatic conditions. In controlled-release fertilizers, in turn, solubilization is dependent on the thickness of the membrane covering the granule, which controls water intake and reduces nutrient dissolution (Sangoi et al., 2016).

The main advantages of the use of slowrelease nitrogen fertilizers are reduced losses by volatilization, leaching, and denitrification; regular and continuous supply of nutrients to the plants; less frequency of application to the soil; reduction of damage to seeds and roots caused by high concentration of salts; reduced contamination of groundwater and surface water caused by nitrate $\left(\mathrm{NO}_{3}{ }^{-}\right)$; and reduced production costs (Valderrama et al., 2009; Sangoi et al., 2016).

Studies have shown that the use of these fertilizers is an effective strategy to increase and improve $\mathrm{N}$ supply in maize, besides allowing total $\mathrm{N}$ fertilization to take place at sowing (Bono et al., 2008; Frazão et al., 2014). Also, when high $\mathrm{N}$ rates are required in the soil (above $100 \mathrm{~kg} \mathrm{ha}^{-1}$ ), slow-release urea is the most indicated source, since it is able to gradually release the necessary $\mathrm{N}$ for plants, further enabling single dose application at sowing (Farmaha \& Sims, 2013).

Conventional urea incorporated into the soil has a higher agronomic efficiency when compared to slow-release urea, since it is cheaper than the latter (Civardi et al., 2011). However, this practice becomes unfeasible when using no-tillage system. Hence, new studies are needed to clarify the disadvantages and advantages of the use of this fertilizer in agriculture, especially in the conditions of the south region of Brazil, where there are few studies on the use of slowrelease urea.

Therefore, this study evaluates the effect of the application of slow-release and conventional urea at different times, analyzing maize development and yield, as well as the fertilizer use efficiency by plants.

\section{Materials and methods}

The experiment was conducted from November 2017 to April 2018 in Santa Rosa do Sul - SC, located between the following coordinates: $29^{\circ} 06^{\prime} 56^{\prime \prime}$ South latitude and $49^{\circ} 48^{\prime} 56^{\prime \prime}$ West longitude. The soil is classified as Red Argisol (EMBRAPA, 2013).

According to the Köppen classification, the climate of the region is type Cfa, subtropical humid, with mean annual temperature of $19.2^{\circ} \mathrm{C}$ and mean annual rainfall of $1600 \mathrm{~mm}$. Figure 1 shows the daily rainfall and temperature data during the period of the experiment.

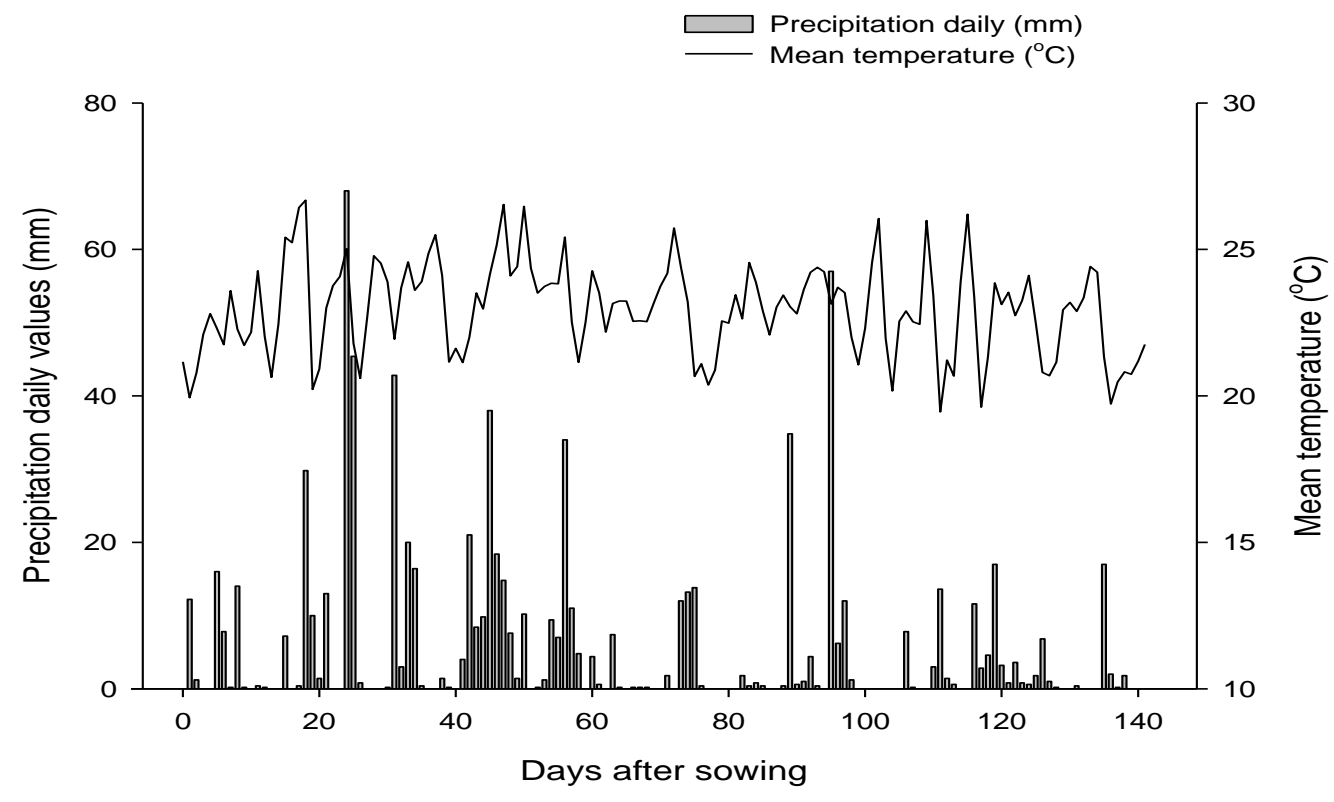

Figure 1 - Precipitation (rainfall) daily values and mean air temperature recorded during the experiment. Data obtained at Araranguá, SC, experimental station in the period of 11/25/2017 to 4/19/2018. Source: Brazilian Agricultural Research Corporation of Santa Catarina (EPAGRI). 
A soil analysis was performed prior to the installation of the experiment to evaluate chemical attributes (Table 1) and clay percentage. Samples were randomly collected in the experimental area, at 0-0.2 m depth, using a Dutch auger. Next, these samples were taken to the laboratory for further analysis. The results were interpreted with the aid of the Liming and Fertilizing Manual for the states of Rio Grande do Sul and Santa Catarina (CQFS, 2016), based on the expected yield of $10 \mathrm{tha}^{-1}$.

Table 1 - Chemical attributes and clay percentage of the experimental area soil in the layer 0-0,2 $\mathrm{m}$.

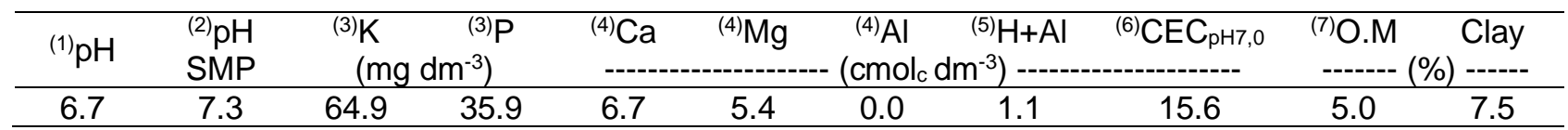

${ }^{(1)} \mathrm{pH}$ in water; (2) $\mathrm{pH}$ measured after addition of SMP solution; (3) $\mathrm{P}$ and K: Mehlich-1 extractor; (4) $\mathrm{Ca}, \mathrm{Mg}$ and Al: extractor $\mathrm{KCl}$ $1 \mathrm{~mol} \mathrm{~L}^{-1} ;{ }^{(5)} \mathrm{H}+$ Al: extractor calcium acetate $0.5 \mathrm{~mol} \mathrm{~L}^{-1} ;{ }^{(6)} \mathrm{CEC}_{\mathrm{pH} 7,0}$ : cation exchange capacity at $\mathrm{pH}$ 7.0; ${ }^{(7)} \mathrm{O} . \mathrm{M}$.: Organic matter $=$ C.org $\times 1.724$.

The experimental design was a randomized complete block design with five treatments and three replicates. Treatments consisted of two nitrogen sources and two application times: T1 - control, without $\mathrm{N}$ application; $\mathrm{T} 2-100 \%$ of the $\mathrm{N}$ rate in the form of conventional urea (CU) at sowing; T3 - 30\% of the recommended $\mathrm{N}$ rate in the form of conventional urea at sowing and $70 \%$ at topdressing; T4 - 100\% of the recommended $\mathrm{N}$ rate in the form of slow-release urea (Sulfammoß) at sowing; T5 - 30\% of the recommended $\mathrm{N}$ rate in the form of slow-release urea (SRU) at sowing and $70 \%$ at topdressing.

Sowing was performed in a no-tillage system, under white oat straw (Avena sativa), on November 29, 2017. The simple hybrid Agroeste 1551 Pro2 was used to obtain a population of 65,000 plants in the spacing of $0.65 \mathrm{~m}$ between rows. Each plot was composed of six $5-\mathrm{m}$ long planting rows, totaling an area of $19.5 \mathrm{~m}^{2}$ per experimental plot. In the evaluation of yield and yield components, the two central rows of each plot were considered as useful area $\left(6.5 \mathrm{~m}^{2}\right)$.

Base fertilization comprised $112 \mathrm{~kg} \mathrm{ha}^{-1} \mathrm{~N}$ as conventional urea $(45 \% \mathrm{~N})$ and slow-release urea $(29 \% \mathrm{~N})$, according to each treatment; $140 \mathrm{~kg} \mathrm{ha}^{-1} \mathrm{~K}_{2} \mathrm{O}$ and $150 \mathrm{~kg} \mathrm{ha}^{-1} \mathrm{P}_{2} \mathrm{O}_{5}$ as potassium chloride $\left(58 \% \mathrm{~K}_{2} \mathrm{O}\right)$ and triple superphosphate $\left(41 \% \mathrm{P}_{2} \mathrm{O}_{5}\right)$, respectively. Topdressing nitrogen fertilization was performed with the corresponding dose of each treatment at 26 days after sowing (DAS), when plants were at the V4 phenological stage.

Weed control was carried out in post-emergence with the aid of a backpack equipment, using the herbicide glyphosate due to the resistance of the cultivar to the compound. The predominant weeds in the experiment area were tropical spiderwort (Commelina benghalensis) and wild buckwheat (Polygonum convolvulus). Control of leaf-cutting ants was performed at 7 days after emergence (DAE) with fipronil-based granular insecticide $(0.01 \%)$.

Soil levels of ammonium $\left(\mathrm{NH}_{4}{ }^{+}\right)$and nitrate $\left(\mathrm{NO}_{3}{ }^{-}\right)$were determined to verify the stabilization moment of $\mathrm{N}$ values and to associate it with the time of release of the fertilizers in the soil. Evaluations started at 13 DAS on December 12, 2017 and were repeated every 7 days to verify the behavior of fertilizers after their application. Collections ended on January 3,
2018 , when $\mathrm{N}$ values stabilized.

Samples were collected using a Dutch auger at $0-0.1 \mathrm{~m}$ depth. Three subsamples were taken to compose a sample, one in the row and two in between rows in each experimental plot. Immediately after removal, samples were taken to the laboratory for extraction and determination of soil $\mathrm{N}$ by distillation (Tedesco et al., 1995).

When the crop reached the R1 phenological stage, leaf chlorophyll content, ear insertion height, and stem diameter were analyzed in eight plants in the useful area of each plot. Leaf $\mathrm{N}$ content was measured with the electronic chlorophyll meter clorofiLOG, model CFL1030, using the index leaf for the reading, which corresponds to the leaf located in the same stem node where the main ear is inserted (Mota et al., 2015). Ear insertion height was measured from the ground to the ear base with the aid of a tape measure. Stem diameter was determined by means of a manual pachymeter, at $0.2 \mathrm{~m}$ above the ground.

Harvest was done manually in the useful area of each plot on April 19, 2018, at 137 DAE, when grains presented about $24 \%$ moisture. All ears from the useful area of the plots were harvested and the straw was removed. Subsequently, the following evaluations were performed: Ear diameter, measured with a digital pachymeter in the middle region of the ear; Ear length, with a digital pachymeter measuring the distance from the first to the last grain; Number of rows per ear: counting each ear individually; Number of grains per row and Number of grains per ear: determined from the count of 20 ears representative of each plot, counting all grains.

After evaluation of yield components, all ears were manually threshed to determine crop yield. The grains from each plot were weighed in an analytical balance and the grain moisture of each plot was determined with an electronic meter, model Motomco 919 FOB. Yield was determined from weight and humidity data with the aid of Calcagro application (version 1.0.6).

Equation 1.

Nitrogen use efficiency was calculated through

$N U E=(Y f-Y w f) / A N a$ 
Wherein: NUE is the agronomic efficiency $\left(\mathrm{kg} \mathrm{kg}^{-1}\right), \mathrm{Yf}$ is the grain yield with nitrogen fertilizer $(\mathrm{kg})$, Ywf is the grain yield without nitrogen fertilizer $(\mathrm{kg})$, and $\mathrm{ANa}$ is the amount of $\mathrm{N}$ applied $(\mathrm{kg})$.

Data regarding the performed evaluations were submitted to analysis of variance and $\mathrm{F}$ test $(p<0.05)$. When significant, the means were compared by the Tukey test $(p<0.05)$ with the aid of the SISVAR program, version 5.6.

\section{Results and discussion}

With different sources and application times, $\mathrm{N}-\mathrm{NO}_{3}{ }^{-}$contents presented similar behavior throughout the evaluation period, with a peak at 20 days after sowing (Figure 2). Topdressing fertilization occurred at 16 days after sowing, which explains the more marked increase in nitrate content when SRU was split applied (T5). In the split application of conventional urea (T3), the increase was much lower when compared to the split application of SRU, since with immediate solubilization the compound becomes more susceptible to losses. The decrease in contents after 20 DAS can be due to leaching losses, favored by high rainfall in the period (Figure 1). Although the use of slow-release fertilizers may delay urea hydrolysis and, consequently, the nitrification process, it is not efficient in reducing leaching losses accumulated for a certain a period (Dal Molin et al., 2018).

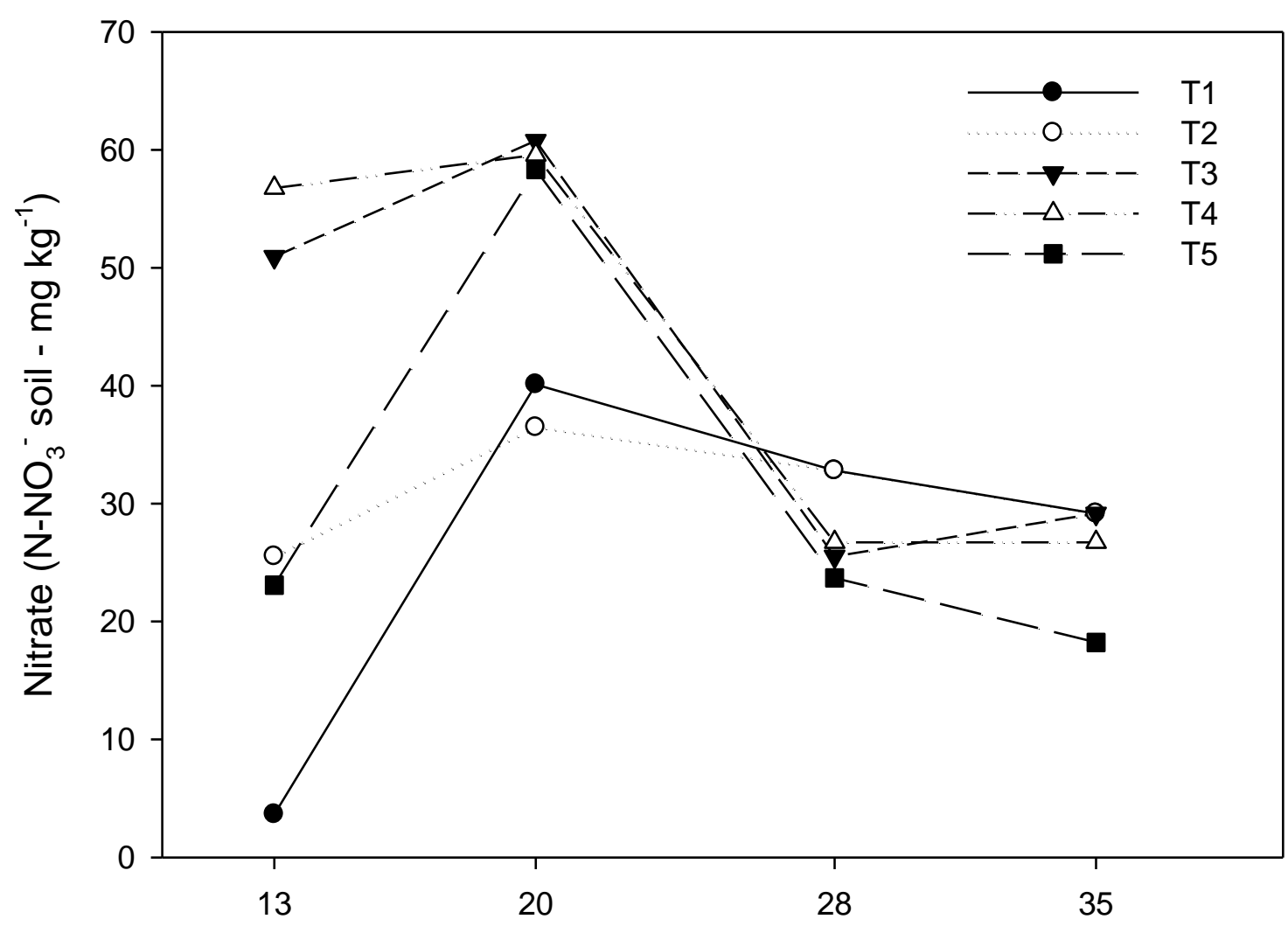

Days after sowing

Figure 2 - ${\mathrm{N}-\mathrm{NO}_{3}}^{-}$soil contents $\left(\mathrm{mg} \mathrm{kg}^{-1}\right)$ according to nitrogen sources and application: $\mathrm{T} 1$ - control; $\mathrm{T} 2$ - conventional urea in total dose at sowing; T3 - conventional urea split (sowing and topdressing); T4 - slow release urea in total dose at sowing; T5 - slow release urea split (sowing and topdressing).

For $\mathrm{N}-\mathrm{NH}_{4}{ }^{+}$contents, there are differences in the release behavior of the nitrogen source (Figure 3). Slow-release urea (SRU) allowed frequent and gradual release for 28 days after sowing, regardless of the time of $\mathrm{N}$ application. With the use of $\mathrm{CU}$, there was a slight decrease in availability when the application was made at planting, followed by an increase from 20 DAS. The same behavior was observed in the control and in the treatment with split application of urea. This decrease may be due to nitrification, favored by $\mathrm{pH}$ conditions above 6.0 (Silva et al., 2005), since it coincides with the increase of $\mathrm{NO}_{3}{ }^{-}$in the same period (Figure 2). The subsequent increase, even in the treatments with no topdressing application, is probably due to the mineralization of organic matter by microorganisms (aiming at the addition or maintenance of the available soil N) and/or by white oat straw decomposition, which was already in an advanced stage. 


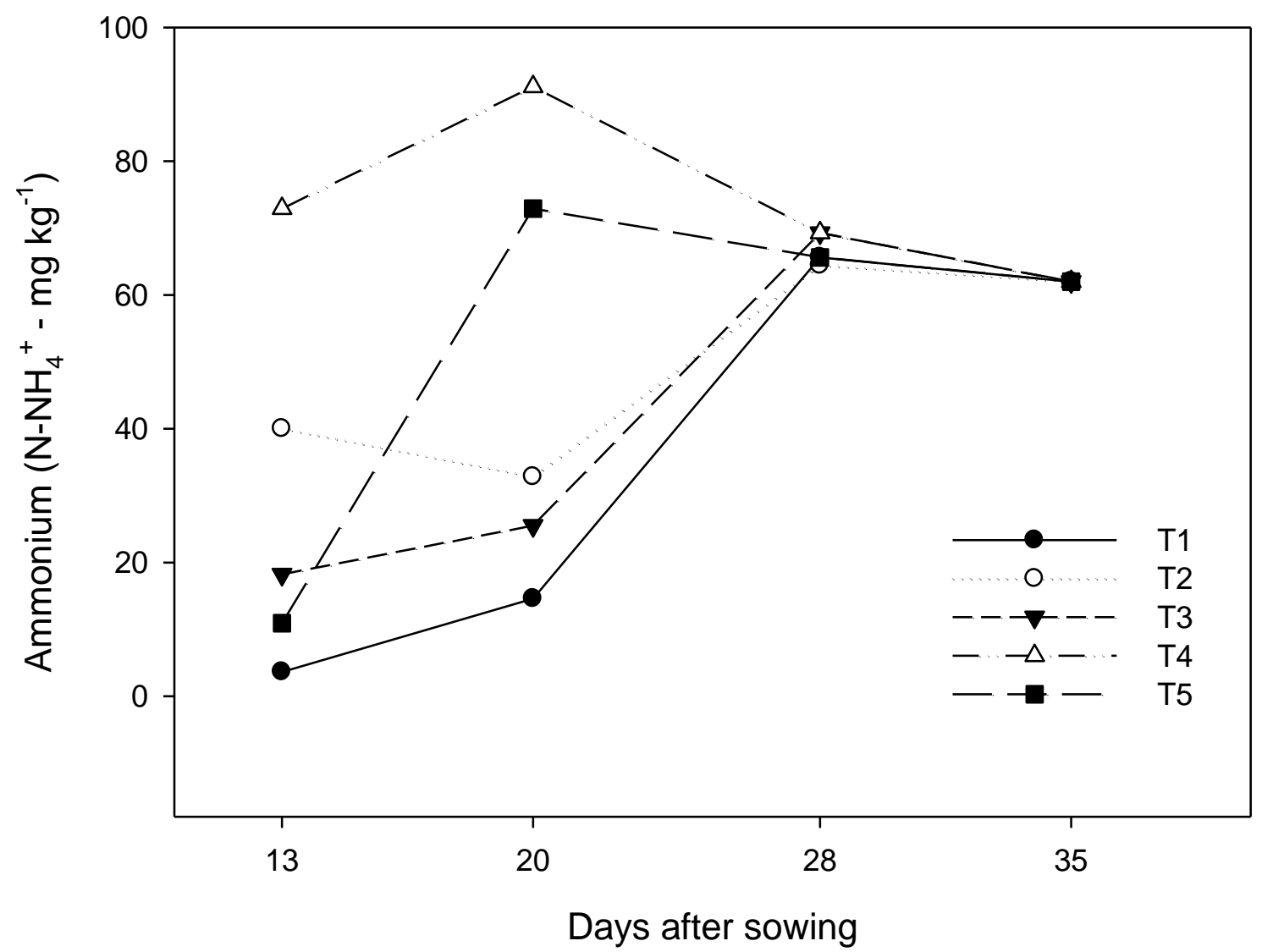

Figure 3 - N-NH $4{ }_{4}^{+}$soil contents $\left(\mathrm{mg} \mathrm{kg}^{-1}\right)$ according to nitrogen sources and application: $\mathrm{T} 1$ - control; T2 - conventional urea in total dose at sowing; T3 - conventional urea split (sowing and topdressing); T4 - slow release urea in total dose at sowing; T5 - slow release urea split (sowing and topdressing).

The $\mathrm{NH}_{4}{ }^{+}$contents obtained in the first evaluation were much higher in the treatment with SRU application at sowing compared to the $\mathrm{CU}$ applied in the same period (Figure 3). This is due to the higher losses occurring by volatilization with the use of conventional urea, which is rapidly solubilized (Martins et al., 2014), resulting in a peak of ammonia volatilization occurring in the first four days after fertilizer application (Faria et al., 2013). These losses are favored by the conditions observed in the present study, such as high $\mathrm{pH}$, high temperatures, and average soil moisture (Ernani, 2016; Tasca et al., 2011).

Knowledge of the $\mathrm{N}-\mathrm{NH}_{4}{ }^{+} / \mathrm{N}^{-}-\mathrm{NO}_{3}{ }^{-}$ratio in the cultivation system is of great importance in plant $\mathrm{N}$ uptake, since $\mathrm{N}$ is predominantly absorbed by the roots in the form of $\mathrm{NH}_{4}{ }^{+}$and $\mathrm{NO}_{3}{ }^{-}$(Silva et al. 2010). Normally, $\mathrm{NO}_{3}{ }^{-}$is the most absorbed source, but the form of $\mathrm{N}$ absorption depends, among other factors, on soil $\mathrm{pH}: \mathrm{NH}_{4}{ }^{+}$absorption is favored by high $\mathrm{pH}$, contrary to $\mathrm{NO}_{3}^{-}$, which is favored by low pH (Ruaro et al., 2009).

Regarding availability, soil $\mathrm{pH}$ below 6.0 tends to favor the permanence of $\mathrm{N}$ as $\mathrm{NH}_{4}^{+}$, retarding the nitrification process (Silva et al., 2005). In the present study, higher levels of $\mathrm{NH}_{4}{ }^{+}$were observed in relation to $\mathrm{NO}_{3}{ }^{-}$at the end of the evaluation period, even with soil $\mathrm{pH}$ above 6.0. This was possibly due to the contribution of $\mathrm{NH}_{4}^{+}$provided by the mineralization of organic matter, contrasting to $\mathrm{NO}_{3}{ }^{-}$losses by leaching. According to the literature, the use of cover crops may provide higher amounts of ammonium in the soil (Malavolta, 1980; Holzschuh et al., 2009). Although grasses have a high $\mathrm{C} / \mathrm{N}$ ratio, which in many situations may reduce soil $\mathrm{N}$ availability, this does not prevent an increase in nitrogen content, especially when there is an adequate supply of this nutrient in the soil.

Considering the availability of total mineral $\mathrm{N}$ $\left(\mathrm{NH}_{4}{ }^{+}+\mathrm{NO}_{3}{ }^{-}\right)$, the treatment with $\mathrm{SRU}$ application at sowing was superior to the others, since it provided the highest levels throughout the evaluated period, indicating that it is possible to avoid topdressing application and guarantee an adequate $\mathrm{N}$ supply to the plants.

Analysis of variance showed that the treatments did not affect ear insertion height, while leaf chlorophyll content presented a lower value only in the control treatment. Stem diameter differed significantly among all treatments (Table 2). 
Table 2 - Leaf chlorophyll content, stem diameter and ear insertion height with $\mathrm{N}$ application as conventional urea $(\mathrm{CU})$ and slow release urea (SRU) with application at sowing or splitted at sowing plus in topdressing.

\begin{tabular}{lccc}
\hline Treatments & Leaf chlorophyll content & $\begin{array}{c}\text { Stem diameter } \\
(\mathrm{mm})\end{array}$ & $\begin{array}{c}\text { Ear insertion height } \\
(\mathrm{cm})\end{array}$ \\
\hline T1 - Control & $50.31 \mathrm{~b}$ & $19.52 \mathrm{c}$ & $152.00 \mathrm{a}$ \\
T2 - CU (sowing) & $58.73 \mathrm{a}$ & $23.10 \mathrm{~b}$ & $146.96 \mathrm{a}$ \\
T3 - CU (sowing and topdressing) & $58.58 \mathrm{a}$ & $24.50 \mathrm{ab}$ & $150.08 \mathrm{a}$ \\
T4 - SRU (sowing) & $58.66 \mathrm{a}$ & $25.26 \mathrm{ab}$ & $147.46 \mathrm{a}$ \\
T5 - SRU (sowing and topdressing) & $61.01 \mathrm{a}$ & $25.90 \mathrm{a}$ & $148.66 \mathrm{a}$ \\
\hline CV (\%) & 1.74 & 3.34 & 1.76 \\
\hline
\end{tabular}

Means followed by the same letters in the columns do not differ from each other by the Tukey test $(p>0.05)$.

According to Vargas et al. (2012), leaf chlorophyll content is a good parameter to evaluate soil $\mathrm{N}$ availability and may be more indicative than mineral soil $\mathrm{N}$ content. Thus, except for the control, all treatments provided sufficient levels for plant development. The frequent and well distributed rains during the crop cycle (Figure 1) favored the solubilization of both fertilizers, guaranteeing an adequate supply.

According to Argenta et al. (2001), the adequate level of $\mathrm{N}$ in maize leaves, when measured with SPAD chlorophyll meter, is around 58.0 at the R1 development stage, which highlights the results found in the present study. Testing rates of conventional urea and urea coated by different polymers in a dystrophic Red Latosol, Valderrama et al. (2014) obtained average chlorophyll contents around 63 , with no differences between treatments, showing that the use of urea with different coatings did not affect the nutritional status $(\mathrm{N})$ of the plant.

The lowest stem diameter was observed in the control, without $\mathrm{N}$ application, and the highest values were found in the treatments with split application of SRU at sowing (Table 2). This is due to the fact that $\mathrm{N}$ acts in vegetative growth, directly influencing cellular division, expansion, and the photosynthetic process, promoting an increase in plant height and stem diameter (Silva et al., 2005; Fornasieri Filho, 2007). The application time and dose splitting can affect stem diameter, providing or not the nutrient in the period of greater demand by the plant, but the absence of nitrogen fertilization results in thinner stems (Cruz et al., 2008).

Stem growth in maize plants happens mainly from the emission of the eighth leaf, extending until flowering. Moreover, the stem not only acts as a support for leaves and inflorescences, but mainly as a structure intended for the storage of soluble solids that will be used for grain formation. Thus, the stem diameter of maize plants is very important to achieve high grain yield. The larger the stem diameter, the greater the plant's capacity to store photoassimilates that will contribute to grain filling (Fancelli \& Dourado Neto, 2000).

Yield components were not influenced by application times and $\mathrm{N}$ sources (Table 3). With the exception of ear diameter, which showed no difference in any treatment, the other variables presented significant results only when the treatments were compared to the control.

Table 3 - Number of grains per row, number of rows per ear, number of grains per ear, diameter of ear and length of ear with $\mathrm{N}$ application as conventional urea (CU) and slow release urea (SRU) with application at sowing or splitted at sowing plus in topdressing.

\begin{tabular}{lccccc}
\hline Treatments & $\begin{array}{c}\text { Grains/ } \\
\text { row }\end{array}$ & $\begin{array}{c}\text { Rows/ } \\
\text { Ear }\end{array}$ & $\begin{array}{c}\text { Grains/ } \\
\text { Ear }\end{array}$ & $\begin{array}{c}\text { Ear diameter } \\
(\mathrm{cm})\end{array}$ & $\begin{array}{c}\text { Ear length } \\
(\mathrm{cm})\end{array}$ \\
\hline T1 - Control & $29.3 \mathrm{~b}$ & $13.8 \mathrm{~b}$ & $400.0 \mathrm{~b}$ & $4.4 \mathrm{a}$ & $12.1 \mathrm{~b}$ \\
T2 - CU (sowing) & $35.3 \mathrm{a}$ & $14.6 \mathrm{a}$ & $506.3 \mathrm{a}$ & $4.5 \mathrm{a}$ & $14.2 \mathrm{a}$ \\
T3 - CU (sowing and topdressing) & $35.3 \mathrm{a}$ & $15.0 \mathrm{a}$ & $510.0 \mathrm{a}$ & $4.6 \mathrm{a}$ & $14.3 \mathrm{a}$ \\
T4 - SRU (sowing) & $35.0 \mathrm{a}$ & $14.7 \mathrm{a}$ & $507.7 \mathrm{a}$ & $4.6 \mathrm{a}$ & $14.7 \mathrm{a}$ \\
T5 - SRU (sowing and topdressing) & $36.0 \mathrm{a}$ & $15.0 \mathrm{a}$ & $529.7 \mathrm{a}$ & $4.6 \mathrm{a}$ & $14.4 \mathrm{a}$ \\
\hline CV (\%) & 4.48 & 1.38 & 3.46 & 1.94 & 2.44 \\
\hline
\end{tabular}

Means followed by the same letters in the columns do not differ from each other by the Tukey test $(p>0.05)$.

Mean ear length is one of the variables that can directly interfere with maize yield and number of grains per row (Kappes et al., 2009). Ear length is defined when the plants have 12 fully expanded leaves; any adversity such as lack or excess of nutrients may result in a reduction in this variable and, as a consequence, a reduction in yield (Dourado Neto et al., 2004).
Ear diameter, in turn, is often related to grain filling and to the number of grain rows per ear (Ohland et al., 2005). According to studies, the number of rows per ear is a component dependent on the plant's genetic potential and on environmental conditions (Valderrama et al., 2011; Caires \& Milla, 2016). For this reason, there was no interaction between $\mathrm{N}$ sources and application times in this study. 
Nitrogen fertilization increased the average maize yield by $30 \%$ compared to the control treatment. Moreover, thousand grain weight, one of the main yield components, was also increased (Table 4). Notwithstanding, the number of ears per hectare was not significantly altered by treatments.

Table 4 - Number of ear per hectare, mass of a thousand grains and corn yield with $\mathrm{N}$ application as conventional urea (UC) and slow release urea (ULL) with application at sowing or splitted at sowing plus in topdressing.

\begin{tabular}{lccc}
\hline Treatments & Ears per hectare & $\begin{array}{c}\text { Mass of } 1000 \\
\text { grains }(\mathrm{g})\end{array}$ & $\begin{array}{c}\text { Yield } \\
\left(\mathrm{kg} \mathrm{ha}^{-1}\right)\end{array}$ \\
\hline T1 - Control & $57949 \mathrm{a}^{(2)}$ & $261.3 \mathrm{~b}$ & $6149 \mathrm{c}$ \\
T2 - CU (sowing) & $60000 \mathrm{a}$ & $287.0 \mathrm{ab}$ & $7133 \mathrm{ab}$ \\
T3 - CU (sowing and topdressing) & $65641 \mathrm{a}$ & $316.0 \mathrm{a}$ & $8369 \mathrm{ab}$ \\
T4 - SRU (sowing) & $65128 \mathrm{a}$ & $324.3 \mathrm{a}$ & $7944 \mathrm{ab}$ \\
T5 - SRU (sowing and topdressing) & $61538 \mathrm{a}$ & $332.0 \mathrm{a}$ & $8615 \mathrm{a}$ \\
\hline CV (\%) & 12.67 & 5.80 & 10.94 \\
MSD $^{(1)}$ & 22191.27 & 49.73 & 2359.73 \\
\hline
\end{tabular}

${ }^{(1)} \mathrm{MSD}=$ minimum significant difference. ${ }^{(2)}$ Means followed by the same letters in the columns do not differ from each other by the Tukey test $(p>0.05)$.

The highest values of thousand grain weight were verified in treatments with $\mathrm{N}$ application compared to the control (Table 4). The same result was observed in the studies conducted by Cruz et al. (2008) and Queiroz et al. (2011), who found differences only in relation to the control or with increasing $\mathrm{N}$ rates, regardless of the application time or source, respectively. On the other hand, in the studies of Bono et al. (2008) and Guareschi et al. (2013), in addition to increased nutrient availability, the use of slow-release urea resulted in a higher thousand grain weight compared to the use of conventional urea, also improving seed physiological quality. These different results in the literature can occur due to differences between the genetic materials used in the research and especially due to the environmental conditions of the experiments, since the water regime may influence the response potential (Martins et al., 2014).

Regarding yield, there was also a statistical difference between the treatments that received fertilization and the control (Table 4). The highest absolute values were obtained with split SRU application, which promoted an increase of $28.63 \%$ in crop yield compared to the control. Studies have shown that split $\mathrm{N}$ application results in higher yields, since a better distribution allows higher uptake by the crop and lower losses in the system (Da Ros et al., 2003; Silva et al., 2005). Moreover, the literature also points to increased yield with the use of more efficient fertilizers, such as slow-release urea (Guareschi et al., 2013; Frazão et al., 2014). Nevertheless, this increase is conditioned to water availability (Faria et al., 2013; Martins et al., 2014).

The number of ears per hectare, which is directly related to the number of ears per plant, did not present significant differences between treatments. The number of ears per plant is a production component that undergoes genetic influence. Some maize hybrids (such as that of the present study) are prolific, that is, they may present one to two ears per plant under favorable environmental conditions (Albuquerque et al., 2013). Notwithstanding, the experiment showed that although each plant emitted two ears, only one managed to complete its development.

Nitrogen use efficiency was affected by the treatments. The highest efficiency was obtained with split SRU application, while the other treatments did not differ among themselves (Table 5).

Table 5 - Nitrogen use efficiency (NUE) by maize crop with $\mathrm{N}$ application as conventional urea (CU) and slow release urea (SRU) with application at sowing or splitted at sowing plus in topdressing.

\begin{tabular}{lc}
\hline Treatments & $\mathrm{NUE}\left(\mathrm{kg} \mathrm{kg}^{-1}\right)$ \\
\hline T1 - Control & - \\
T2 - CU (sowing) & $8.79 \mathrm{~b}$ \\
T3 - CU (sowing and topdressing) & $19.82 \mathrm{~b}$ \\
T4 - SRU (sowing) & $16.03 \mathrm{~b}$ \\
T5 - SRU (sowing and topdressing) & $22.02 \mathrm{a}$ \\
\hline CV (\%) & 56.87
\end{tabular}

Means followed by the same letters in the columns do not differ from each other by the Tukey test $(p>0.05)$.

The low efficiency found with total CU application at sowing compared to split SRU application is due to the fact that $\mathrm{CU}$, like most nitrogen fertilizers, is a water-soluble fertilizer, quickly converted into forms that can be lost by leaching or volatilization. This re- duces the nutrient use efficiency of cereals, especially when fertilizers are applied in large quantities and with a single application (Fan et al., 2004).

Similarly, single SRU application at sowing also resulted in a lower $\mathrm{N}$ use efficiency by the plants 
when compared to split SRU application. Despite reducing ammonia volatilization losses (Nascimento et al., 2013), frequent rains may increase leaching losses (Martins et al., 2014; Dal Molin et al., 2018). This may have been one of the factors that led to such results. In the first thirty days after sowing, rainfall of more than 60 $\mathrm{mm}$ occurred in only one day (Figure 1), thus reducing the period of nutrient availability to the plant.

\section{Conclusions}

Under high rainfall conditions, slow-release urea may be an alternative for maize nutrition, since it increases the nutrient use efficiency of plants when split applied.

The application of slow-release urea resulted in an increase in maize stem diameter due to the longer time for $\mathrm{N}$ release in the soil, with greater use by the plant.

\section{References}

Albuquerque AW, Santos JR, Moura Filho G, Reis LS (2013) Plantas de cobertura e adubação nitrogenada na produção de milho em sistema de plantio direto. Revista Brasileira de Engenharia Agrícola e Ambiental 17(7):721-726. doi: http://dx.doi.org/10.1590/S141543662013000700005

Argenta G, Silva PRF, Bortolini CG (2001) Clorofila na folha como indicador do nível de nitrogênio em cereais. Ciência Rural 31(4):715-722. doi: http://dx.doi.org/10.1590/S0103-84782001000400027

Austin AT, Bustamante MC, Nardoto GB, Mitre SK, Perez T, Ometto JPJB, Ascarrunz NL, Forti MS, Longo K, Gavito ME, Enrich-Prast A, Martinelli LA (2013) Latin America's nitrogen challenge. Science 340:149. doi: $10.1126 /$ science. 1231679

Bono JAM, Rodrigues APAC, Mauad M, Albuquerque JC, Yamamoto CR, Chermouth KS, Freitas ME (2008) Modo de aplicação de fertilizantes nitrogenados na qualidade fisiológica de sementes de milho. Agrarian 1(2):91-102.

Caires EF, Milla R (2016) Adubação nitrogenada em cobertura para o cultivo de milho com alto potencial produtivo em sistema de plantio direto de longa duração. Revista Bragantia 75(1):87-95. doi: http://dx.doi.org/10.1590/1678-4499.160

Civardi EA, Silveira Neto AN, Ragagnin VA, Godoy ER, Brod E (2011) Ureia de liberação lenta aplicada superficialmente e ureia comum incorporada ao solo no rendimento do milho. Pesquisa Agropecuária Tropical 41(1):52-59.

http://dx.doi.org/10.5216/pat.v41i1.8146

Chien SH, Prochnow LI, Cantarella H (2009) Recent developments of fertilizer production and use to improve nutrient efficiency and minimize environmental impacts. Advances in Agronomy 102:267-322. doi: https://doi.org/10.1016/S0065-2113(09)01008-6
CQFS - Comissão de Química e Fertilidade do Solo RS/SC (2016) Manual de calagem e adubação para os Estados do Rio Grande do Sul e de Santa Catarina. SBCS. 376 p.

Cruz SCS, Pereira FRS, Santos JR, Albuquerque AW, Silva ET (2008) Parcelamento da adubação nitrogenada na cultura do milho irrigado em sistema plantio direto. Revista Brasileira de Engenharia Agrícola e Ambiental 12(4):370-375. doi: http://dx.doi.org/10.1590/S1415-43662008000400006

Da Ros CO, Salet RL, Porn RL, Machado JNC (2003) Disponibilidade de nitrogênio e produtividade de milho e trigo com diferentes métodos de adubação nitrogenada em plantio direto. Ciência Rural 33(5)799-804. doi: http://dx.doi.org/10.1590/S010384782003000500002

Dal Molin SJ, Ernani PR, Soldatelli P, Cassol PC (2018) Leaching and recovering of nitrogen following $N$ fertilizers application to the soil in a laboratory study. Communications in Soil Science and Plant Analysis 49(9):1099-1106.doi: 10.1080/00103624.2018.1448860

Dourado Neto D, Favarin JL, Manfron PA, Pilau FG, Soares MA, Bonnecarrère AG, Ohse S (2004) Efeito do boro e nitrogênio na cultura do milho. INSULA Revista de Botânica 33:51-67.

EMBRAPA - Empresa Brasileira de Pesquisa Agropecuária (2013) Sistema brasileiro de classificação de solos. Embrapa Solos. 353p.

Ernani PR (2016) Química do solo e disponibilidade de nutrientes. $\mathrm{O}$ autor. $256 \mathrm{p}$.

Fan X, Li F, Liu F, Kumar D (2004) Fertilization with a new type of coated urea: Evaluation for nitrogen efficiency and yield in winter wheat. Journal of Plant Nutrition 27(5):853-865.

https://doi.org/10.1081/PLN-120030675

Fancelli AL, Dourado Neto D (2000) Produção de miIho. Agropecuária. $360 \mathrm{p}$.

Faria LA, Nascimento CAC, Vitti GC, Luz PHC, Guedes SEM (2013) Perdas de $\mathrm{N}_{-} \mathrm{NH}_{3}$ de fertilizantes nitrogenados aplicados em palhadas de milho e de soja. Revista Brasileira de Ciência do Solo 37(4):969-975. doi: http://dx.doi.org/10.1590/S0100-

\section{4}

Farmaha BS, Sims AL (2013) The influence of PCU and urea fertilizer mixtures on spring wheat protein concentrations and economic returns. Agronomy Journal 105:1328-1334. doi: 10.2134/agronj2012.0454

Fornasieri Filho D (2007) Manual da cultura do milho. Funep. 576 p. 
Frazão JJ, Silva AR, Silva VL, Oliveira VA, Corrêa RS (2014) Fertilizantes nitrogenados de eficiência aumentada e ureia na cultura do milho. Revista Brasileira de Engenharia Agrícola e Ambiental 18(12):12621267. doi: http://dx.doi.org/10.1590/18071929/agriambi.v18n12p1262-1267

Guareschi RF, Perin A, Gazolla PR (2013) Produtividade de milho submetido à aplicação de ureia revestida por polímeros. Global Science and Technology 06(02):31-37. doi: http://dx.doi.org/10.14688/19843801.v06n02a04

Guo J, Wang Y, Blaylock AD, Chen X (2017) Mixture of controlled release and normal urea to optimize nitrogen management for high-yelding (>15 $\left.\mathrm{Mg} \mathrm{ha}^{-1}\right)$ maize. Field Crops Research 204:23-30. doi: https://doi.org/10.1016/j.fcr.2016.12.021

Holzschuh MJ, Bohnen H, Anghinoni I, Meurer EJ, Carmona FC, Costa SEVGA (2009) Resposta do arroz irrigado ao siprimento de amônio e nitrato. Revista Brasileira de Ciência do Solo 33(5):1323-1331. doi: http://dx.doi.org/10.1590/S0100-06832009000500025

Kappes C, Carvalho MAC, Yamashita OM, Silva JAN (2009). Influência do nitrogênio no desempenho produtivo do milho cultivado na segunda safra em sucessão a soja. Pesquisa Agropecuária Tropical 39(3):251259.

Malavolta E (1980) Elementos da nutrição mineral de plantas. Ceres. 251p.

Martins IS, Cazetta JO, Fukuda AJF (2014) Condições, modos de aplicação e doses de ureia revestida por polímeros na cultura do milho. Pesquisa Agropecuária Tropical 44(3):271-279. doi: http://dx.doi.org/10.1590/S1983-40632014000300010

Mota MR, Sangoi L, Schenatto DE, Giordani W, Boniatti CM, Dall'Igna L (2015) Fontes estabilizadas de nitrogênio como alternativa para o rendimento de grãos e a eficiência de uso do nitrogênio pelo milho. Revista Brasileira de Ciência do Solo 39(2):512-522. doi: http://dx.doi.org/10.1590/01000683rbcs20140308

Nascimento CAC, Vitti GC, Faria LA, Luz PHC, Mendes FL (2013) Ammonia volatilization from coated urea forms. Revista Brasileira de Ciência do Solo 37:10571063. doi: http://dx.doi.org/10.1590/S010006832013000400022

Ohland RAA, Souza LCF, Hernani LC, Marchetti ME, Gonçalves MC (2005) Culturas de cobertura do solo e adubação nitrogenada no milho em plantio direto. Ciência e Agrotecnologia 29(3):538-544. doi: http://dx.doi.org/10.1590/S1413-70542005000300005
Queiroz AM, Souza CHE, Machado VJ, Lana RMQ, Korndorfer GH, Silva AA (2011) Avaliação de diferentes fontes e doses de nitrogênio na adubacão da cultura do milho (Zea mays L.). Revista Brasileira de Mi$\begin{array}{lll}\text { lho } & \text { Sorgo } & \text { 10(3):257-266. }\end{array}$ doi:http://dx.doi.org/10.18512/1980-

6477/rbms.v10n3p257-266

Ruaro L, Lima Neto VC, Ribeiro Júnior PJ (2009) Influência do boro, de fontes de nitrogênio e do pH do solo no controle de hérnia das crucíferas causada por Plasmodiophorabrassicae. Tropical Plant Pathology 34(4):231-238. doi: http://dx.doi.org/10.1590/S198256762009000400005.

Sangoi L, Silva PRF, Pagliarini NHF (2016) Estratégias de manejo da adubação nitrogenada em milho na região sul do Brasil. Graphel. 122p.

Silva EC, Buzetti S, Guimarães GL, Lazarini E, Sá ME (2005) Doses e épocas de aplicação de nitrogênio na cultura do milho em plantio direto sobre Latossolo Vermelho. Revista Brasileira de Ciência do Solo 29:353-362. doi: http://dx.doi.org/10.1590/S010006832005000300005

Silva PCC, Couto JL, Santos AR (2010) Efeito dos íons amônio e nitrato no desenvolvimento do girassol em solução nutritiva. Revista da Faculdade de Zootecnia, Veterinária e Agronomia 17(1):104-114.

Tasca FA, Ernani PR, Rogeri DA, Gatiboni LC, Cassol PC (2011) Volatilização de amônia do solo após a aplicação de ureia convencional ou com inibidor de urease. Revista Brasileira de Ciência do Solo 35:493502. doi: http://dx.doi.org/10.1590/S010006832011000200018

Tedesco MJ, Gianello C, Bissani CA, Bohnen H, Volkweiss SJ (1995) Departamento de Solos da Universidade Federal do Rio Grande do Sul. Análise de solo, plantas e outros materiais. UFRGS. 174p.

Valderrama M, Buzetti S, Benett CGS, Andreotti M, Arf O, Sá ME (2009) Fontes e doses de nitrogênio e fósforo em feijoeiro no sistema plantio direto. Pesquisa Agropecuária Tropical 39(3):191-196.

Valderrama M, Buzetti S, Teixeira Filho MCM, Benett CGS, Andreotti M (2014) Adubação nitrogenada na cultura do milho com ureia revestida por diferentes fontes de polímeros. Semina: Ciências Agrárias 35(2):659-670.

\subsection{4v35n2p659}

Vargas VP, Sangoi L, Ernani PR, Siega E, Carniel G, Ferreira MA (2012) Os atributos nas folhas são mais eficientes que o $\mathrm{N}$ mineral no solo para avaliar a disponibilidade desse nutriente para o milho. Bragantia 71(2):245-255. doi: http://dx.doi.org/10.1590/S000687052012000200014 